\title{
NA DANÇA DOS ALTARES: A ORDEM DO CARMO E A IRMANDADE DA BOA MORTE ENTRE O PODER E A SOBREVIVÊNCIA NO RIO DE JANEIRO DOS PRIMEIROS TEMPOS DO IMPÉRIO (1814-1826)
}

\author{
Sandra Rita Molina \\ Mestre pela Unicamp
}

\begin{abstract}
Resumo
Este artigo analisa as relações entre a Província Carmelita Fluminense e a Irmandade de Nossa Senhora da Boa Morte da Vila de Angra dos Reis na Província do Rio de Janeiro entre os anos de 1814 e 1826 . Em um contexto de confronto entre o poder público, o poder da tradição incorporado pela Igreja Católica e a subseqüente produção de uma legislação anti-clero regular, pretende-se compreender de que maneira tal panorama alterou as estratégias de sobrevivência dos protagonistas.
\end{abstract}

\section{Abstract}

The purpose of this article is to analyze the relationship between the carmelite monks and the "Irmandade da Boa Morte" in the village of Angra dos Reis between 1814 and 1826. In these years, there was an increasing conflict between the State and the Catholic Church with the subsequent production of a regular anti-clergy legislation. The intention of this paper is to understand how this new context interfered in the survival strategies of the protagonists.

\section{Pallavras-Chave}

Ordem Regular • Irmandade • Legislação • Igreja Católica • Império

\section{Keywords}

Regular Order $\bullet$ Irmandade $\bullet$ Legislation $\bullet$ Catholic Church $\bullet$ Empire 
E m 1822 no contexto da proclamação da Independência e das discussões políticas sobre quais os rumos adequados ao país, alguns moradores da vila de Ilha Grande de Angra dos Reis vivenciavam um conflito não menos intenso de busca de independência em seu cotidiano. Tratava-se de um processo que envolveu tradicionais códigos sociais e religiosos que, no século XIX brasileiro, estavam imbricados à política nacional.

Nesse ano, a Irmandade de Nossa Senhora da Boa Morte solicitava ao Imperador a transferência de sua sede que se achava na igreja do Convento de Nossa Senhora do Carmo dessa vila, para a igreja de Nossa Senhora da Lapa que então se encontrava sob seqüiestro do Estado. Justificava seu pedido traçando um histórico de desrespeito religioso e institucional progressivamente efetivado pelos frades carmelitas que eram os proprietários da igreja na qual se localizava o altar da Boa Morte ${ }^{1}$.

Durante o período colonial, um dos "serviços sociais" prestados pelas ordens religiosas era justamente a assistência às confrarias de diferentes configurações, dentre elas as ordens terceiras e as irmandades ${ }^{2}$. A irmandade de Nossa Senhora da

\footnotetext{
${ }^{1}$ Eram frades carmelitas calçados pertencentes à Província Carmelita Fluminense. A Ordem dos Carmelitas Calçados, tradicionalmente tem sua origem por volta de 900 a.C. quando o Profeta Elias retirou-se para o Monte Carmelo na então chamada Terra Santa iniciando um grupo de eremitas. Entretanto uma outra versão mais burocrática atesta que a origem da ordem está na Idade Média. Em 1156, um cruzado oriundo da Calábria, chamado Bertoldo, cumprindo uma promessa, retirouse com alguns companheiros para o Monte Carmelo onde construíram uma vida comum seguindo o exemplo do Profeta Elias. No século XIII os antigos eremitas já haviam se transformado em uma ordem regular com conceitos, administração e burocracia definida edificando, inclusive, seus primeiros conventos na Europa e especificamente, na cidade de Moura, o eremitério que marcou a chegada dos carmelitas em terras portuguesas. Trata-se da ordem masculina também chamada Ordem Primeira. Uma ordem regular, entretanto dividia-se ainda em Ordem Segunda (das Monjas ou Feminina) e finalmente dos Irmãos Leigos (também conhecida como Ordem Terceira). Ver: Regra e Constituições dos religiosos da O. da B. sempre Virgem Maria do Monte Carmelo da Antiga e regular Observância...1749; (Pratt 1941; Benedetti Filho 1990; Almeida1926: 126, I).

2 "Quanto às Irmandades religiosas no Brasil, elas aparecem mais ligadas às confrarias medievais, de finalidade religiosa e caritativa. Apesar de que essas associações gradualmente tivessem desaparecido, é inegável que muitos dos objetivos e características das antigas confrarias européias continuaram nas irmandades mineiras, com idênticos cultos e festividades de suas congêneres européias do passado, exercendo, ao mesmo tempo, atividades sociais semelhantes. Tanto a proteção à seus membros neces-
} 
Boa Morte era formada por homens livres de posses modestas, em sua grande maioria pardos e que não dispunham de capela própria para o culto de sua padroeira. Por essa razão, em acerto com os carmelitas usavam o altar lateral na igreja do convento ${ }^{3}$.

No ano de 1814 o prior responsável pelo convento havia se aproveitado de uma pequena reforma na igreja, destruído o altar da Senhora da Boa Morte e recolhido a imagem à sacristia "ficando desde então a Senhora sem culto e a Irmandade sem o altar e até aniquilada quase extinta" (Mendes 1980: 95-96). Posteriormente sob o governo de outro Prior e a pedido da irmandade, foi designado um novo altar lateral para a Senhora podendo então os irmãos da Boa Morte continuar em atividade.

Contudo, desde esse episódio a irmandade não teve mais tranqüilidade para o exercício de seu culto. Isso por que sendo composta de "homens pardos e pobres, e os Priores cada um tem[endo] seu gênio diferente, ora são[eram] os Irmãos injuriados em suas qualidades e a Irmandade tratada com desprezo, ora abusam[vam] os Priores dela e dão[vam] as sepulturas privativas da Irmandade a quem lhes parece, até da grande despesa que a Irmandade é[era] obrigada a fazer em sua Festividade, tendo os beneplácitos do Prior atual, que umas vezes são[eram] mais acomodados, outras mais excessivos pela falta de Regimento nas funções eclesiásticas, que tudo tende[ia] de seus arbítrios" (Apud Mendes: 95-96).

A disputa que se desenhou a partir de 1814 ia além de uma simples questão de altares. Tratava-se de um momento de reordenação da realidade social, religiosa e política presente desde o século XVIII naquela vila. Eram as exigências de um grupo

sitados, como a construção de obras religiosas e mesmo profanas, foram exercidas pelas irmandades mineiras, seguindo caminhos semelhantes aos que percorriam no passado as confrarias alienígenas." Ver: Scarano (1978).

${ }^{3}$ João José Reis também aborda a relação entre irmandades e ordens regulares da seguinte maneira: "As confrarias, divididas principalmente em irmandades e ordens terceiras, existiam em Portugal desde o século XIII pelo menos, dedicando-se a obras de caridade voltadas para seus próprios membros ou para pessoas carentes não associadas. Tanto as irmandades quanto as ordens terceiras, embora recebessem religiosos, eram formadas sobretudo por leigos, mas as últimas se associavam a ordens conventuais (franciscana, dominicana, carmelita), daí se originando seu maior prestígio.”Ver: (Reis 1999: 49). 
de pobres e pardos lutando com uma das mais importantes e prestigiadas ordens regulares do Brasil, a Província Carmelita Fluminense. Eram súditos exigindo regimentos que interferissem e regrassem o interior de uma instituição privada e proprietária a fim de que não se sentissem ameaçados em seu culto. Tratava-se enfim, da substituição de uma convivência tradicional por uma nova ordem que emergia simultaneamente ao processo da Independência.

Mas o que era a Província Carmelita Fluminense de início do século XIX? Por que esta ordem regular ainda em 1822 insistia em manter sob sua "proteção" o altar da Boa Morte? Por que se preocupar com uma irmandade formada por 'homens pardos e pobres'? Por que os irmãos da Boa Morte montaram uma peça documental direcionada diretamente ao Estado ao invés de focar sua necessidade de independência nos circuitos religiosos como seria de se esperar pela sensibilidade do homem do século XIX?

Para responder a essas questões torna-se necessário informar o leitor sobre o que era e o significado da Província Carmelita Fluminense no Brasil oitocentista.

Os Carmelitas Calçados chegaram ao Brasil ainda no século XVI e até o século XVIII viveram sob um regime de subordinação política em relação à Província Carmelita Portuguesa. A Ordem Carmelita Brasileira, a partir de 1720, dividiu-se territorialmente em regiões administrativas chamadas províncias, favorecendo uma maior autonomia. A sede da principal unidade se localizava na cidade do Rio de Janeiro, constituindo a Província Carmelita Fluminense.

A Província Carmelita Fluminense abarcava diversos conventos com suas respectivas propriedades, atuando como gerenciadora central da política, administração e economia desenvolvida separadamente por cada convento. Constavam dessa Província os seguintes conventos: o de Santos, o do Rio de Janeiro, o de São Paulo, o de Angra dos Reis da Ilha Grande, o de Mogi das Cruzes, o de Vitória do Espírito Santo e o de Itu. Mesmo localizados em cidades diferentes com contextos específicos, havia um modus operandi comum e que era orientado e formatado pela política da sede provincial e pelos principais conventos: do Rio de Janeiro, de São Paulo e de Santos ${ }^{4}$.

Havia uma autonomia elevada no gerenciamento das propriedades da ordem o que acarretou, ainda no século XVIII, graves problemas de natureza disciplinar in- 
terna e atritos entre a Província Carmelita Fluminense e a Coroa Portuguesa . Após a intervenção, os carmelitas retomaram progressivamente sua autonomia administrativa através dos Capítulos Definitoriais e da eleição de priores responsáveis pelo gerenciamento do patrimônio específico a cada convento.

Entretanto essa reconquista da autonomia seria barrada ainda nas primeiras décadas do século XIX, quando as ordens regulares se viram envolvidas em um universo de enfrentamento mais amplo: o confronto entre o Estado e a Igreja no Brasil Imperial. A disputa pela delimitação dos campos de atuação específicos, possibilitou a reedição e a elaboração de inúmeras leis que, no limite, visavam reformar o clero em geral e especificamente procuravam restringir o clero regular no Brasil ${ }^{6}$.

O Estado imperial, ao longo do século XIX, reafirmou um procedimento legislativo de constrangimento às ordens regulares cujos pontos essenciais foram elaborados no século XVIII. Tais leis visavam o controle do poder eclesiástico e criaram uma prática que interferiu no cotidiano interno dessas ordens e em suas atividades

\footnotetext{
${ }^{4} \mathrm{Na}$ sede provincial (o convento da Côrte) se estabelecia a etapa preparatória inicial dos noviços do carmelo, e era também onde se realizavam as reuniões denominadas Capítulos e Congregações Definitoriais da Província Carmelitana Fluminense. Eram reuniões que teoricamente deveriam realizar-se em um período trienal e que contavam com a presença de representantes de cada um dos conventos da Província Carmelita Fluminense. Nessa reunião eram tomadas as decisões referentes a administração do patrimônio da corporação e eleitos os frades responsáveis pelos conventos e respectivas propriedades pelos anos seguintes.

${ }^{5}$ Um desses atritos originou uma Reforma decretada pela Coroa Portuguesa e supervisionada pelo Bispo Diocesano do Rio de Janeiro, nomeado Visitador Apostólico. Tal Reforma ocupou o período entre 1785 e 1800 e configurou-se em uma intervenção direta do Estado Secular (representado pela Coroa Portuguesa através do Visitador Apostólico), na organização interna dos frades carmelitas calçados. Um dos resultados imediatos dessa Reforma foi uma significativa diminuição do número de seus frades. Em 1785 somavam 141 religiosos e logo após o final da Reforma, em 1803, contavam apenas 49 religiosos (Molina 1998).

${ }^{6}$ Importante notar que a Igreja Católica Apostólica Romana não pode ser considerada um corpo homogêneo com idéias uniformes e projetos políticos definidos apenas pela alta hierarquia Romana. Especificamente em se tratando dos quadros que a formam, vale destacar uma divisão fundamental que é a do Clero Secular e a do Clero Regular. Em linhas gerais, tal divisão do clero surgiu no final do Império Romano do Ocidente e ao longo do período medieval da necessidade da Igreja Católica organizar sua hierarquia e administração. O Clero Secular deveria cuidar dos assuntos temporais da Igreja, zelar
} 
junto às comunidades onde se estabeleciam. Assim, o presente artigo procura compreender em uma situação bastante específica de conflito entre uma dessas ordens regulares reprimida pelo Estado imperial - a Província Carmelita Fluminense e a Irmandade da Boa Morte - de que maneira tal legislação alterou as estratégias de sobrevivência dos dois lados envolvidos na disputa.

No debate acerca da delimitação dos espaços do poder público e do poder privado, o principal foco de interesse do império eram as ordens mais tradicionais e poderosas que aos olhos do Estado nacional que se criava, insistiam em constituir, graças a sua autonomia administrativa, um estado dentro do Estado imperial.

Esse era o caso da Província Carmelita Fluminense que juntamente com os beneditinos eram consideradas as duas corporações regulares mais ricas do Brasil Imperial. Tais religiosos possuíam um enorme volume de propriedades de todos os tipos: desde aquelas constituídas por igrejas, conventos e hospícios, até outras ditas mais "leigas" como grandes fazendas, imóveis urbanos como casas residenciais e de comércio, além de mais de uma centena de escravos. Contudo, somado à ostentação econômica, os carmelitas possuíam um fascínio que estava relacionado com a sua inserção no cotidiano da sociedade leiga na qual se situava. Ainda no século XIX muitas conversões e crises místicas ocorriam dentro dos templos carmelitanos. O próprio bispo de São Paulo, D. Antonio de Mello, foi tocado pelo espírito religioso, decidindo tornar-se padre em uma crise mística durante uma missa de natal numa Igreja do Carmo da vila de Itu em São Paulo (Fontoura 1898: 21-25; Camargo 1953: 29).

Segundo a descrição dos memorialistas, na cidade de São Paulo, por exemplo, eram do convento dos carmelitas, aliados a sua ordem terceira, as missas mais sun-

pelas coisas da vida, possuir um contato maior com os fiéis, cuidar do cotidiano de sua vida terrena para assegurar o futuro de sua alma; enfim tratar do saeculum. O Clero Regular, por sua vez, surgiu da necessidade de valorização da espiritualidade: era formado por monges residentes em mosteiros e conventos, cujas vidas eram regidas por diretrizes bastante específicas que definiam votos como caridade, castidade, silêncio e, em muitos casos, a pobreza. Por pautarem-se em uma vida mais voltada à espiritualidade e à contemplação, desenvolveram um cuidado maior na preparação intelectual de seus frades e na preservação da cultura ocidental. Ver: Donini (1988) e Boaga (1989). 
tuosas, as mais tocantes semanas santas e as cerimônias matrimoniais mais prestigiadas. Dentro de uma sociedade na qual olhos falavam mais do que mil palavras, a ostentação cerimonial do Carmo era muito ressaltada .

Suas procissões, atraíam não só os grandes de então, mas também o povo estava em peso nas ruas como se fossem festas nacionais. De acordo com Paulo Cursino de Moura, as procissões carmelitas eram as mais concorridas no calendário religioso do século XIX paulista. Com cunho oficial, com acompanhamento da nobreza, com andores e pálios carregados até pelo Presidente da Província. A esse propósito, estavam sempre na ordem do dia, as ciumarias oficializadas, discutidas e apuradas em documentos públicos e pela imprensa em que cônegos e chantres se misturavam com priores, ouvidores, corregedores nas mais pueris contendas pelo fato de, na Procissão dos Passos, ou na do enterro, o barão de tal não ter sido convenientemente, cerimoniosamente, distinguido com uma cana do pálio da sagrada relíquia (Moura 1943: 48; Bruno 1984).

Uma poderosa proprietária particular e simultaneamente um símbolo cerimonial principalmente para a elite católica imperial. Assim era a Província Carmelita Fluminense que se viu progressivamente invadida por questões como a disputa com a Irmandade da Boa Morte iniciada em 1814.

Um ponto de grande tensão entre o poder temporal e o clero regular foi a decisão de restringir o direito de propriedade plena conferido aos regulares por D. João VI, uma vez que a Câmara procurou restabelecer os direitos do Estado sobre o patrimônio das ordens religiosas, concebendo-os como bens indisponíveis, em última instância para serem utilizados no entendimento do interesse público ${ }^{8}$.

\footnotetext{
${ }^{7}$ É importante notar que, durante os séculos XVIII e XIX, apenas aquelas Ordens Regulares indicadas e beneficiadas por um Breve da Cúria Romana poderiam realizar cerimônias consideradas fundamentais e de grande responsabilidade para o calendário religioso tais como as referentes à Semana Santa. No Brasil, nesse período, a única Ordem que possuía tal autorização era a Província Carmelita Fluminense, que por si só, demonstra uma parcela de seu prestígio junto à sociedade de então.
} 
Os padrões adotados para justificar a restrição às ordens ao longo do século XIX instrumentalizaram muitas práticas já vivenciadas no final do século anterior e também adequaram-se ao discurso de construção de uma idéia de nação e cidadania que, por um lado, retomavam ideais do XVIII e, por outro, ainda estavam por ser delineadas.

"O bispo da Bahia Frei Francisco de São Dâmaso (1814-1816) ensina, em pastoral, que o principal dever do cidadão é ser vassalo fiel; devem os párocos insistir no dever de obediência ao soberano, pois 'não pode amar a Deus quem não ama o seu legítimo soberano'. Um bom cristão não pode ser mau cidadão, mas é mau cidadão 'aquele que, não se conformando com os preceitos de sua religião, dá ouvidos à inquieta, turbulenta voz da rebelião, que arrasta após de si todos os vícios, horrores e desordens, além de desafiar toda a cólera e as mais terríveis maldições da divindade'; os confessores inquiram com o maior cuidado os penitentes a respeito e lhes mostrem que pecam mortalmente todas as vezes que desobedecem a seus soberanos ou a seus ministros, porque é desobedecer ao mesmo Deus. Os confessores são responsáveis perante Deus de todos os males que pela sua incúria sobrevierem à sociedade, ao Estado e à Religião"(Hoornaert 1992: 14).

O clero em geral era visto como responsável pela formação de súditos fiéis. Brasileiros obedientes à legislação, moralizados e disciplinados aos moldes europeus. Essa tarefa pedagógica era relegada à Igreja tradicionalmente vista como pastora de almas.

Após a Independência, o clero secular demonstrava uma participação política considerável no processo de construção das leis no Estado que se formava. Dessa forma, essa parcela do clero bem como o próprio culto religioso estavam atrelados ao Estado, criando vínculos de dependência extremamente fortes. Assim, as reformas nas capelas, igrejas, a compra de alfaias para a realização das missas e a sobrevivência dos religiosos seculares deveriam adequar-se ao orçamento do Governo Provincial, num primeiro momento, e posteriormente, ao Imperial.

\footnotetext{
8 “Com relação às Ordens Religiosas particularmente, a idéia dominante era a supressão gradual. (...) [adotara-se o conceito dominante de que as Ordens Monásticas] eram, quanto aos seus bens, meras detentoras, administradoras e usufrutuárias de um patrimônio cujo domínio direto pertencia ao Estado.” (Barbosa 1902: 29-30; Benedetti Filho 1990:168).
} 
As funções desses religiosos estavam então delimitadas: enquanto funcionários remunerados pelo Estado, o clero deveria assegurar a educação civil do cidadão e que se atrelava à idéia de educação moral. Apenas por meio do ensino de princípios de moralidade contidos na doutrina cristã e nos exemplos dados cotidianamente pelos sacerdotes é que a ordem social seria preservada. Tratava-se da necessidade do Estado moderno que se construía, ou seja, a secularização da vida civil dos brasileiros utilizando-se de uma parceria já tradicional na dominação da população, ou seja, a instituição católica.

Contudo, a Igreja Católica do Brasil do século XIX vivia um processo de redefinição, uma transição que muitos países europeus já haviam solucionado e que o regalismo português e o Império haviam barrado no Brasil. Durante a idade média, a mentalidade vigente indicava que o dever de salvar o homem era tarefa da Igreja e não do Estado, afinal tratava-se de uma das poucas instituições fortes e relativamente centralizadas desse período. O Estado era visto como seu auxiliar. Em razão da maldade inata ao homem, a hierarquia secular (reis e nobres), por meio da aplicação do medo e da coação, deveria controlar o espaço material. Contudo, a grande responsabilidade ainda pertencia a Igreja, que se auto-atribuía a finalidade de levar o homem ao reino de Deus.

Entretanto, sobretudo a partir do século XVIII, cada vez mais delineou-se um conflito intenso entre o Estado e a Igreja, que se deparava com as idéias de construção de um mundo no qual sobrava pouco espaço para as verdades reveladas e negavamse a fé e a religião como único caminho para a construção do saber. Passava-se à edificação racional do Estado e de sua plena soberania em relação à Igreja. O Estado moderno traz embutido em si as idéias de nascimento de uma nova moral, a moral do homem que construiu o Estado e, portanto, a necessidade de criação de uma ética nacional que fosse racionalizada, separada da teologia. A teoria moderna de Estado apoiou-se sobre a tese dos três poderes - legislativo, executivo e judiciário - e das relações entre eles. Uma vez reduzido o conceito de Estado ao de política, e o conceito de política ao de poder, a questão mais importante a ser resolvida dizia respeito à possibilidade de se diferenciar o poder político de todas as outras formas que a relação de poder assumia (Altoé 1993: 43-45). 
O que as leis do início do século XIX demonstram é justamente essa dificuldade no estabelecimento da jurisdição do poder público e do poder privado no Brasil. O tenso relacionamento entre Estado imperial e o clero regular se iniciou ainda com a política pombalina e o conflito se agravou com a instalação do Estado nacional. Em decorrência desse processo, tornou-se relativamente comum nos relatos das autoridades religiosas do oitocentos, a presença de reclamações sobre o quanto o Império "opressor" os desrespeitava e de como a Igreja "sofria" por não ter quem a protegesse dentro do espaço do poder temporal.

“(...) Entre nós a opressão exercida pelo Estado em nome de um pretenso Padroado foi uma das principais causas do abatimento da nossa Igreja, do seu atrofiamento quase completo.

Era uma proteção que nos abafava. Não eram só intrusões contínuas nos domínios da Igreja; era frieza sistemática, para não dizer, desprezo, respondendo quasi sempre a urgentíssimas reclamações d'ela; era a prática de deixar as dioceses por largos anos viuvas dos seus pastores, sem se atender ao clamor dos povos e à ruína das almas; era o apoio oficial dado aos abusos que estabeleciam a abominação da desolação do lugar santo; era a opressão ferrea a pesar sobre os institutos religiosos, eflorescência necessária da vida cristã, vedando-se o noviciado, obstando-se a reforma, e espiando-se baixamente o momento em que expirasse o último frade, para se por mão viva sobre esse sagrado patrimônio chamado mão morta".(Pastoral de 19 de março de 1890: 46)

De fato, a opressão legislativa marcou as relações tensas entre Estado e Igreja ao longo do século XIX. Entretanto, contrariando a imagem mais recorrente na historiografia, tal situação não era uma inovação oitocentista, pois a Igreja, particularmente as ordens regulares, já se habituara, especialmente a partir do século XVIII, a decifrar as regras dos jogos de poder a serem desenvolvidos entre o mundo secular e o religioso e, sobretudo, a enfrentar pesadas intervenções em suas práticas.

Por outro lado, o Estado imperial trouxe uma experiência inédita: a convivência com um poder a mais a intervir nas teias dessas relações - o legislativo. Cabe, nesse momento, indagar como os regulares se adaptariam às novas regras do jogo: se a intervenção era de fato incontornável ou se oferecia possibilidades de preservação 
de formas de atuação construídas ao longo da vida colonial e que haviam tecido, estruturalmente, a Província Carmelita Fluminense.

O século XIX não apresentou apenas um genérico conflito entre Estado e Igreja, nem uma posição submissa desta última em relação ao primeiro. Analisando mais detidamente a documentação sobre a Província Carmelita Fluminense, é possível observar que, os confrontos foram mais complexos e que as clássicas percepções de cumplicidade inerente à Igreja e seu clero caem por terra. Sobretudo entre o Estado imperial e as ordens regulares estabeleceu-se uma complexa relação de (des)obediência essencial para garantir tanto os objetivos do Estado, quanto a autonomia e sobrevivência dos religiosos ${ }^{9}$.

Ao invés de instituições uniformes e coerentes - Igreja e Estado, por exemplo - surgiram grupos nuançados, complexos e atuantes, empenhados na defesa de seus interesses particulares. Por exemplo, a Igreja mostrou-se cindida em pelo menos duas instâncias profundamente delimitadas: o clero secular e o regular. Enquanto o primeiro se apresentou profundamente subordinado ao Governo, o segundo emergiu, ao lado de outros cidadãos brasileiros (proprietários de terras, imóveis e escravos), defendendo acirradamente direitos tradicionais frente ao poder Imperial. Assim, os regulares compunham congregações autônomas, que seguiam orientações diversas e tiveram desempenhos específicos.

No tocante aos carmelitas, então, diante da constituição do Império do Brasil, fazia-se necessária a imediata reformulação de seu lugar e de sua imagem dentro da nova idéia de nação a ser construída. Qual deveria ser o perfil desses frades? Poderiam assumir, tanto quanto os padres seculares, cargos políticos? Quais as fron-

\footnotetext{
${ }^{9}$ A profunda contradição intrínseca às relações entre o estado monárquico e as ordens regulares foi bem apreendida por Roberto Romano: "O regime monárquico procurava anular as ordens religiosas, mas manter, a seu serviço, um clero capaz de prosseguir funcionando como garantia de ordem. Esta era, afinal, uma orientação contraditória: para que houvesse influência efetiva da Igreja, era necessário que sua pregação e propaganda tivessem continuidade: liquidando-se aquelas ordens, aniquilavam-se exatamente os elementos disponíveis para este trabalho, comprometendo-se a esperada colaboração." (Romano 1979: 93). Daí a contraditória orientação que combinaria o controle dos bens e a admissão de noviços e a moralização do desempenho religioso e laico.
} 
teiras que delimitavam sua cidadania? O fato da Província Carmelita Fluminense ser uma grande proprietária lhe garantia que espaço de "barganha" frente às novas instituições e ao poder público? Qual a imagem que melhor representava os carmelitas no século XIX? Com certeza já não se encaixava mais na missão de ordem guardadora das fronteiras do Império Ultramarino Português, ou de prestadores de serviços religiosos profundamente envolvidos com os interesses da sociedade laica.

A busca de um perfil diferenciado para o clero regular em geral e para os carmelitas em particular estaria presente ao longo do século XIX. Sobretudo porque as ordens manteriam estreitos vínculos com o Estado, remanescentes do período colonial, fato que dificultaria a conformação de um clero completamente diverso daquele que se constituíra até o século XVIII. Tais permanências restringiriam a autonomia dos regulares, mas também permitiriam a preservação de práticas tradicionais de independência vivenciadas durante a colonização.

Esse imbricamento entre o poder secular e o religioso se revelou explicitamente também na luta que se estabeleceu em torno da Legislação Anticlero Regular, travada ao longo do século XIX entre as ordens regulares e os signatários do Império. Essa disputa, nem sempre explícita, manifestou-se especialmente no âmbito do legislativo. Mas, em muitos momentos, o palco dessa questão foi também o cotidiano vivenciado pelos religiosos.

Cabe, neste momento, compreender de que maneira os carmelitas da Província Fluminense entendiam e se preparavam para essa disputa. Talvez, a melhor maneira de perceber essa movimentação esteja no acompanhamento de algumas situações difíceis vivenciadas internamente pela ordem nas quais os religiosos procuraram, simultaneamente, adaptar-se às imposições do Estado e garantir sua sobrevivência, remodelando práticas tradicionais. Vejamos um pouco mais dessa atuação na já citada disputa iniciada na primeira década de 1800 entre o Prior do convento da Ilha Grande de Angra dos Reis e a Irmandade da Boa Morte ${ }^{10}$.

No Capítulo Provincial de 16 de abril de 1812, estabeleceu-se a reeleição do Prior Frei José de Santa Gertrudes Ribeiro que residia no convento da Ilha Grande em companhia de apenas um religioso, o Frei José de Jesus Maria ${ }^{11}$. O Prior de Ilha Grande foi reeleito em um momento em que a Província Carmelita Fluminense, 
praticamente recém-saída de uma violenta intervenção conjunta entre clero secular e Estado, buscava retomar sua administração de maneira mais rígida. Dessa forma, ela procurava se encaixar nos padrões de disciplina e de autonomia vigiada estabelecidos através da Reforma vivenciada pela ordem em 1785. Nesse movimento de retomada administrativa, a hierarquia carmelita já havia detectado que seu maior problema era o restrito número de frades remanescentes da Reforma que compunham seus quadros. De acordo com os dados retirados do Livro das Profissões, observase a seguinte movimentação: entre 21 de setembro de 1779 e 24 de junho de 1800 , vinte e um frades professaram; no período entre 24 de junho de 1800 a 11 de novembro de 1810, existiu um acréscimo de quarenta noviços que aceitaram o trabalho na Província Carmelita Fluminense; entretanto, entre 1810 e 1820, o número caiu consideravelmente. Apenas treze frades professaram ${ }^{12}$.

A diminuição do número de frades produziu, uma alteração nos procedimentos administrativos e hierárquicos carmelitas. As reuniões trienais para eleição do Provincial,

\footnotetext{
${ }^{10} \mathrm{O}$ convento de Nossa Senhora do Carmo da Ilha Grande de Angra dos Reis foi fundado em 1593. A chegada dos Carmelitas nesta região foi anterior ao estabelecimento dos Franciscanos e dos Beneditinos.

${ }^{11}$ O que consta é que até então a administração do Prior correspondia aos interesses de conservação e racionalização do patrimônio carmelita, ou seja, desfazer-se de propriedades que pudessem ser inoperantes e, portanto, dispendiosas. Alípio Mendes cita um memorialista que confirma tais informações: "Em 1810, conforme assinala Monsenhor Pizarro, - disso não fazendo qualquer menção o "Livro do Tombo", - foram vendidas as propriedades imobiliárias dos carmelitas, existentes na Ilha da Gipóia, na Ilha do Brandão e na Ilha das Cabras, tudo por seis contos e quatrocentos mil réis, quando o Prior era Frei José de Santa Gertrudes Ribeiro”. (Mendes 1980: 93). Uma outra confirmação de que esse Frei cuidara bem do patrimônio carmelita é o Breve apostólico autorizando que o convento da cidade do Rio de Janeiro usasse para a reforma de seu edifício uma espécie de saldo pertencente ao convento da Ilha Grande e que perfazia a soma de 1:575\$255 réis. Ver: Livro Quarto de Registros, Ordens Reais, Breves e Graças. Alberto Nicholson, Arquivo da Província Carmelita Fluminense (APCF), Belo Horizonte, Minas Gerais.

${ }^{12}$ Um noviço era recebido na Ordem e aceitava o hábito. Passava então por um período preparatório de cerca de um ano e após esse tempo estava formado e então deixava de ser noviço, tornando-se frade. Caso o noviço tivesse pertencido antes a qualquer outra Ordem Religiosa, recebia dispensa de seis meses nessa preparação. Ver: Breves, Circulares e Correspondência do Visitador Apostólico Monsenhor Narciso da Silva Nepomuceno (1860-1861). Alberto Nicholson, APCF.
} 
dos Priores, do Presidente do Capítulo, dos frades Sócios dos Priores que teriam voto no Capítulo ficavam cada vez mais difíceis, dado o pequeno número de frades qualificados para tais funções. Essas dificuldades podem ser percebidas através dos Breves Apostólicos emitidos no mesmo período em que Frei José de Santa Gertrudes Ribeiro foi reeleito para o cargo de Prior do convento de Ilha Grande. Um deles, datado de 15 de abril de 1812, substituiu a reunião do Capítulo, nomeando o Provincial P. M. Frei Inocêncio das Neves Portugal para o cargo de Presidente do Capítulo de 1812 e para Provincial no triênio no período entre 1812 e 1815 . Novamente, em 10 de abril de 1815 , outro Breve Apostólico reiterou tais decisões pelo período entre 1815 e $1818^{13}$.

Esse era o contexto vivenciado pela comunidade carmelita em 1814, momento em que a administração de Frei José de Santa Gertrudes Ribeiro se desentendeu com os Irmãos Leigos da Irmandade de Nossa Senhora da Boa Morte. Desde há muito, a relação entre as duas corporações não caminhava bem e, ao que parece, as atuações de Frei José de Santa Gertrudes só fizeram piorar a situação ${ }^{14}$. Ao retirar a imagem de Nossa Senhora da Boa Morte do altar lateral da Igreja e colocá-la na sacristia, ofendia gravemente a irmandade, pois de certa forma, a ação do Prior sinalizava a pouca importância dada aos símbolos de devoção daquele grupo específico de súditos leigos que congregava os homens pardos da vila de Angra dos Reis.

\footnotetext{
${ }^{13}$ Nesse meio tempo, outras dispensas foram estabelecidas para a Província Carmelita Fluminense. Em 7 de março, o Núncio Apostólico dispensava a realização das eleições de Prelados no Capítulo de 1812. Em 20 de agosto de 1813, outro Breve Apostólico dispensava a eleição dos Sócios dos Priores para os dois Capítulos Provinciais seguintes. Isentava também o Provincial Frei Antonio das Neves Portugal de uma das três Visitas obrigatórias pelas Constituições no próximo sexênio. Ver: o Livro Quarto de Registros, Ordens Reais, Breves e Graças. Alberto Nicholson, APCF.

${ }^{14}$ Sobre o conflito que muitas vezes se estabelecia entre irmandades, ou entre elas e as Igrejas nas quais estavam hospedadas, Mariza Soares de Carvalho em seu estudo sobre o século XVIII no Rio de Janeiro esclarece que: "O crescimento das irmandades faz também crescerem os conflitos. (...) As principais disputas giram em torno de duas questões: de um lado, os conflitos entre irmandades e o poder eclesiástico, e de outro, as disputas entre as próprias irmandades sobre o uso das Igrejas e a precedência nas procissões. Hierarquia e precedência são valores próprios às confrarias, seja no interior de cada uma delas, na sua relação umas com as outras e na relação com a administração eclesiástica." (Carvalho 2000).
} 


\begin{abstract}
"A capela ou igreja era propriedade da irmandade, constituindo um bem coletivo, e as demais irmandades que se criassem ocupavam os altares laterais. Logo que lhes fosse possível, no entanto, tratavam de construir sua própria capela, o que devia garantir-lhes participação mais ativa na vida local. Enquanto só dispunham de altares laterais para as cerimônias do culto, as confrarias iam constituindo 'patrimônio', isto é, adquirindo os bens que lhes permitissem fazer a sua capela. Esta era de caráter provisório e geralmente exígua e devia servir até que tivessem sido angariados os fundos necessários para a construção definitiva, que começava ao redor da antiga construção que se derrubava ou se transformava na capela-mor da nova igreja. Somente as associações que não conseguissem progredir suficientemente continuavam a ser 'associações de altares laterais', ocupando posição secundária nas igrejas de outras irmandades. Todas elas, entretanto, tinham por meta a construção de templo próprio, com o que ganhavam status e maior liberdade de ação.” (Scarano 1976: 30-31).
\end{abstract}

A reação da irmandade não se fez esperar: em 5 de dezembro de 1814, através do Solicitador de Causas Manuel José Chaves, impetrou-se uma ação judicial conhecida como Artigo de Força contra a Província Carmelita Fluminense, intimando para que o Prior de Angra dos Reis explicasse judicialmente os motivos do desmonte do altar de Nossa Senhora da Boa Morte. Explicação que não se realizou, uma vez que, após alguns trâmites legais, o Provincial Frei Inocêncio Antonio das Neves Portugal "providencialmente" substituíra o Frei José de Santa Gertrudes e estabelecera como novo Prior Frei Domingos Pinto de Santa Clara. Esse, não apenas restaurou o altar destruído, depositando em seu nicho a imagem de uma das principais santas carmelitas, Santa Teresa, como também estabeleceu um novo altar para Nossa Senhora da Boa Morte ${ }^{15}$.

Tais decisões eram fruto do momento vivido pela Província Carmelita, que precisava demonstrar obediência e disciplina nos primeiros anos de autonomia administrativa recém-retomada. Eram também resultado das retaliações que os car-

\footnotetext{
${ }^{15}$ Um Breve Apostólico, datado de 29 de abril de 1816, além de dispensar a reunião da Congregação Definitorial de 1816, permitia e confirmava que o P. Frei Domingos Pinto de Santa Clara permanecesse no cargo de Prior do convento de Angra dos Reis. Ver: Livro Quarto de Registros, Ordens Reais, Breves e Graças. Alberto Nicholson, APCF.
} 
melitas haviam sofrido durante a intervenção no século XVIII. Ali aprenderam de que maneira barganhar quando preciso, tanto com o poder secular constituído quanto com o que poderíamos chamar de julgamento de seus fíéis. Portanto, entendiam que naquele momento seria prejudicial, caso o Estado recebesse queixas de leigos contra conventos de qualquer parte do país. O trauma da intervenção sofrida era recente e, além do mais, a esperança de conseguir a entrada de mais noviços era prioridade na administração da Província. Dessa forma, fica mais claro compreender porque, em um momento em que Breves Apostólicos isentavam os religiosos da realização de eleições por falta de número apropriado, o Provincial conseguiu transferir tão rapidamente um frade residente no convento da cidade do Rio de Janeiro para o convento de Ilha Grande, esvaziando, em princípio, as queixas que se pudessem tecer sobre a administração da ordem.

Tratava-se de uma política de extrema boa vontade da parte da hierarquia carmelita. Aos nossos olhos de século vinte e um, essa dança de altares e santos parece irrelevante. Entretanto, para o mundo oitocentista, o significado de esconder uma Nossa Senhora da Boa Morte na sacristia ou de trocá-la por uma Santa Teresa era muito forte. Todos conheciam os códigos que, muitas vezes, iam além de explicações judiciais, pois passavam por um outro tipo de vivência, mais afetiva e tradicional.

Este mesmo código já havia sido utilizado especificamente pelos Irmãos Terceiros da Igreja do Carmo de Ouro Preto na luta pela construção de sua Igreja no século XVIII. Naquele momento, porém, a Província Carmelita Fluminense tinha um poder maior de barganha e prestígio frente à sociedade local e que após a Reforma vivida entre 1785 e 1800 ficou seriamente comprometido. Até 1751, a Ordem Terceira do Carmo residia em um altar lateral da igreja de Nossa Senhora do Pilar. Depois foi transferida para a igreja de Santa Quitéria. Tratava-se de uma "capela de pau a pique". Entretanto a Irmandade de Santa Quitéria possuía uma Capela de sua devoção, mas não os meios para reformá-la ou preservá-la. Por sua vez, os Terceiros do Carmo desejavam a construção de uma igreja independente e seus membros eram organizados o suficiente dentro da vila de Ouro Preto para que conseguissem o dinheiro necessário ao empreendimento. Após uma campanha carmelita de cartas ao 
rei português, finalmente em 1766 um novo acordo foi estabelecido entre os Terceiros e a Irmandade de Santa Quitéria. O terreno da igreja seria utilizado para a ampliação, construção e a manutenção de uma nova igreja consagrada à Nossa Senhora do Monte Carmelo. Entretanto no altar mor ficaria em destaque Nossa Senhora do Carmo e em segundo plano Santa Quitéria, indicando que naquela igreja as duas irmandades eram acolhidas mas quem gerenciava o culto era a ordem terceira mais poderosa, no caso os Carmelitas (Lopes 1942).

No caso da disputa com a Irmandade da Boa Morte, a Santa Teresa reformadora da Ordem no século XVI, e portanto de fundamental importância nos anais do Carmelo, era uma resposta e uma retratação à ofensa feita a Nossa Senhora da Boa Morte que foi escondida em uma mísera sacristia distante da adoração de seus fiéis.

Entretanto, não foi o suficiente. Em 1822, a Mesa Administrativa da Irmandade se movimentou e solicitou ao Imperador D. Pedro I a transferência da sede da irmandade para a igreja de Nossa Senhora da Lapa, então sob o seqüiestro do Estado, medida que a tornaria independente da administração do culto até então gerenciado pelo convento do Carmo (Mendes 1980:95-96).

Os Irmãos da Boa Morte sabiam que o momento político da Independência talvez os favorecesse, não só porque se modificavam os termos do pacto político entre os súditos e o Príncipe como também pelo fato de serem de conhecimento público as restrições do Estado com relação às ordens regulares. Portanto, construíram uma peça documental de certa forma comovedora e astuciosa, no sentido de conquistar a autonomia do culto de sua padroeira. Primeiro, esclareciam que seu pedido era fruto de uma convivência longa, tradicional e que aos poucos tornara-se prejudicial à irmandade ${ }^{16}$. Apontavam então para um possível descontrole dos regulares, uma vez que os Priores mudavam da forma como queriam sua política de convivência com os irmãos leigos. E mais, chamavam a atenção para o fato de que talvez isso ocorresse com aquela

\footnotetext{
${ }^{16}$ A convivência entre Carmo e outras Irmandades em um mesmo espaço parece ter sido uma constante. É o caso por exemplo da Irmandade de Nossa Senhora do Rosário das Portas do Carmo descrito por João Reis. Os seus membros eram forros e escravos que construíram um templo nas Portas do Carmo (atual Pelourinho), no início do século XVIII (Reis 1999: 50).
} 
irmandade simplesmente porque era formada por pardos e pobres. Esse era o pretexto que os levaria ao segundo eixo da argumentação: os gastos que a inconstância e a irresponsabilidade carmelita faziam com que aqueles pobres e devotos irmãos tivessem. Além disso, o Carmo abusava do fato de hospedar em sua igreja a Senhora da Boa Morte. As sepulturas, que tradicionalmente eram exclusividade da irmandade, eram utilizadas como forma de "barganhar" interesses com outros fiéis da Ordem do Carmo. Dessa maneira, utilizavam indevidamente um espaço e um enterro que pertenciam aos irmãos pardos da Boa Morte.

Enfim, a convivência tornara-se intolerável! Mas havia uma solução rápida e pouco dispendiosa: que o Imperador cedesse uma das capelas seqüestradas para que a Irmandade da Boa Morte a utilizasse e conservasse. Assim, se resolveriam dois problemas da Vila de Angra dos Reis, deixando menos encargos à política de padroado do Governo Imperial ${ }^{17}$.

Entretanto, mesmo com toda esta argumentação, ainda em 1825, a irmandade não conseguira a desejada transferência uma vez que os carmelitas mantinham sólidos laços com as autoridades da vila. Assim, os irmãos reiteravam novamente seu pedido de forma mais veemente. Nele ficamos sabendo que, com o culto, o Carmo auferia, além de prestígio, algum lucro com o aluguel do altar, dos ornamentos, dos sinos, das toalhas, dos serviços religiosos:

“....que tendo sofrido até agora o mau tratamento com que tem sido provocados pelos Priores deste convento, já injuriosamente tratando-os (aos Irmãos) de Bodes, seja-lhes permitido usar da mesma expressão daqueles Padres, já demolindo o seu altar, e só depois de alguns anos, por ordem do Provincial o Padre Mestre Frei Inocêncio, lhes foi permitido por a imagem da Senhora em outro altar, já servindo-se das sepulturas da Irmandade, dando-as a quem lhes parece, já finalmente, exigindo da Irmandade pagas exorbitantes de pé de altar, aluguel de ornamentos, sinos, e até de por uma toalha lavada no altar-mor de sua igreja; em certo ano exigiram paga, e porque estes incômodos que a Irmandade tem sofrido alte-

\footnotetext{
${ }^{17}$ Desde 1817, a Igreja da Lapa era administrada pelo Ajudante ou Zelador Luís Antonio de Miranda. Possuía entre seu patrimônio alguns terrenos e casas térreas que estavam sob o seqüestro do poder público (Mendes 1980: 96).
} 
ram segundo o gênio, e condutas dos Priores que vão sucedendo, para evadir tais inconvenientes e poder o culto da Senhora prosperar e propagar-se, e os irmãos atuais continuarem a servir com gosto e devoção e adquirirem maior número que bem sirvam a Nossa Senhora da Boa Morte com toda a submissão, e respeito, pedem a Vossa Majestade Imperial seja servido mandar entregar à Irmandade uma capela, que há nesta vila, intitulada da Senhora da Lapa, (...)"(Apud, Mendes 1980: 97 e 98).

Dessa vez, os irmãos da Boa Morte detalharam mais a situação que enfrentavam no seu relacionamento com o convento do Carmo da Ilha Grande ${ }^{18}$. Em um momento em que se discutiam muito quais seriam os atributos de um bom súdito e o papel das ordens regulares em seu desenvolvimento, essa irmandade alertava para o fato de que os carmelitas a estavam impedindo de exercer sua piedade e vivenciar as boas qualidades de religiosidade e respeito às instituições pedidas aos brasileiros.

Ao que parece, essa segunda rogativa surtiu efeito e, em cumprimento a um Alvará de D. Pedro I, o Juiz de Fora e Provedor de Capelas e Resíduos Bacharel, João Capistrano Rebelo, intimou o então Prior Frei Antônio Inácio do Coração de Jesus Mello a dar explicações sobre a petição de autoria dos irmãos da Boa Morte, o que foi cumprido em 12 de novembro de 1825. Em suas explicações, o Prior negou as acusações imputadas à ordem; ressaltou os danos morais que a transferência acarretaria aos carmelitas e inverteu a denúncia, apontando os interesses da irmandade nesse translado. Como os irmãos leigos, o Prior também utilizou-se do conceito da tradição construída através da convivência. Afinal tratavam-se de setenta e cinco anos de relacionamento entre o Carmo e os irmãos da Senhora da Boa Morte!

Entretanto antes de realizar uma análise da retórica de defesa do Carmo, é importante conhecer um pouco mais sobre o então Prior da Ilha Grande. Na documentação

\footnotetext{
${ }^{18}$ Os Irmãos da Boa Morte tocam em um aspecto que durante anos foi crucial na aceitação de membros dentro da Ordem do Carmo. A limpeza do sangue por muito tempo foi destaque. Importante lembrar do integrante dos Padres do Patrocínio, Frei Jesuíno do Monte Carmelo, que passou por várias avaliações a fim de que fosse aceito na Ordem justamente por ser mulato (Ricci 1998; Pinheiro1870:139).
} 
interna à ordem, consta que Frei Antonio Inácio do Coração de Jesus Mello era natural do Rio Grande e havia sido batizado em 23 de setembro de 1781, na Matriz do Senhor Bom Jesus. Em 1 de julho de 1804, tomou o hábito da Província Carmelitana Fluminense e professou cerca de um ano depois, em 2 de julho de $1805^{19}$. Em 25 de abril de 1812, estava no posto de Prior do convento de Mogi, na Província de São Paulo ${ }^{20}$. Nos mandatos de 1815, 1832, 1838 e 1846, assumiu o comando do convento de Santos como Prior. Na cidade de São Paulo, foi Prior do convento nos triênios de 1819, 1827 , 1849, 1851, 1854 e 1859, quando foi assassinado, ao que parece pelo Processo Crime, por dois escravos pertencentes a esse convento ${ }^{21}$.

Com larga experiência no controle administrativo do patrimônio Carmelita, Frei Antonio Inácio provavelmente aprendeu a contornar com habilidade e astúcia as questões cotidianas que surgiam fosse da convivência dos carmelitas com os fiéis, fosse com o Estado. Era conhecido por ser um bom administrador e também por ter um gênio de difícil convivência ${ }^{22}$.

De posse de tais informações, podemos compreender melhor a montagem do discurso de Frei Antonio Inácio nas explicações sobre a irmandade da Boa Morte.

\footnotetext{
${ }^{19}$ Ver: Lista das Entradas, Tomadas de Hábito e Profissões. Compilação de Frei Alberto Nicholson, DOC 6864, Livro Terceiro dos Relatórios dos Capítulos Provinciais e Congregações Definitoriais, Tábua dos Conventuais no Capítulo de 4 de maio de 1805, APCF.

${ }^{20}$ Este religioso conseguia, ao que parece, lidar bem com os trâmites cada vez mais complicados entre o Estado e a Ordem do Carmo. Em 1810, por exemplo, encontrava-se em licença no Rio Grande do Sul. Pelo que consta, já havia excedido seu tempo de distanciamento e apenas depois de um Aviso Régio de 21 de novembro, produto talvez do expediente de um Provincial esperto, é que Frei Antonio Inácio do Coração de Jesus Mello volta às suas atividades no Carmelo. Ver: Livro Quarto de Registros, Ordens Reais, Breves e Graças. Alberto Nicholson, APCF.

${ }^{21}$ Ver: Livros de Capítulos Provinciais e Congregações Definitoriais, Processo Crime do Arquivo do Estado de São Paulo (Aesp).

${ }^{22}$ O prior Frei Inácio (Antonio Inácio do Coração de Jesus Mello), irascível, de mau gênio e de maus modos, sem que pudesse controlar o seu impulso sangüíneo, tinha expansões de cólera, de impaciência e de impulsividade, determinando atritos, mesmo com pessoas a quem devia consideração no exercício de seu mister de diretor de uma das mais importantes instituições religiosas de seu tempo. Ótimo coração, bondade imensa, virtudes peregrinas, devotamento, espírito de abnegação e disciplina, tudo isso ia por água abaixo e explodia em insopitável impulsão quando tocado pela mínima circunstância desagradável ou pela oportunidade imediata. Daí, o espalhar-se a fama do padre, má, odiosa, irritante. Supõe-se que o brinquedo infantil, chamado "Prior do Carmo", em voga naquela época e no qual a meninada procura uma corda para enforcar o frade, foi criado devido à repercussão dos modos desabridos desse prior nas classes escolares (Moura 1980: 56).
} 
Inicialmente, o Prior do Carmo lembrou o início da convivência entre as duas corporações e indiretamente sugeriu que a irmandade que se fizera vítima não possuía um estatuto legal para seu funcionamento, o que se constituía uma infração aos olhos da Igreja e do Estado ${ }^{23}$. Entretanto, mesmo nessa condição de possível ilegalidade, o Carmo sempre estendera sua beneficência a esses irmãos em nome da manutenção do culto religioso. O Prior qualificava então a transferência da Senhora da Boa Morte para a sacristia e a acusação de abuso e ofensas do Carmo à irmandade de acidentes de percurso inevitáveis em um processo de convivência tão tradicional. Classificava como ambição dos Irmãos da Boa Morte o fato de almejarem administrar uma capela, o que lhes proporcionaria acesso aos emolumentos e outras taxas que eles raramente se sentiam obrigados a pagar ao Carmo. Finalizando sua retórica, Frei Antonio Inácio ressaltava o quanto a trasladação da Santa para uma capela que não fosse da Boa Morte seria mal vista pela sociedade local uma vez que atingiria a reputação da ordem. Essa provavelmente classificaria tal ato como intolerância e falta de caridade do Carmo para com a Senhora da Boa Morte e seus irmãos. Nesse sentido, o Prior transformava a petição dos irmãos em uma vingança e injúria que vitimava o convento do Carmo e seus religiosos, procurando a todo custo preservar uma função tradicionalmente desempenhada na comunidade e que lhe conferia prestígio e poder desde o período colonial.

Ao que parece, mesmo com os problemas de convivência, o Carmo ainda preferia que a Senhora da Boa Morte permanecesse em sua igreja. Por isso recorreu, enquanto

\footnotetext{
${ }^{23}$ O Prior chamava atenção para a inexistência do Compromisso. "As associações leigas, irmandades, confrarias ou arquiconfrarias têm a reger-lhes um Compromisso, lei que estabelece os estatutos da organização, que deve ser conhecida e seguida por todos os membros que antes da admissão prestam juramento. Também dispõem de um corpo dirigente, a assim chamada Mesa. Os irmãos de Mesa, eleitos pelo grupo, são, por sua vez, os que têm direito de voto sempre que seja preciso resolver casos importantes para a organização. Tomando a Irmandade do Rosário do Distrito Diamantino como modelo, podemos ver que a Mesa consta dos seguintes elementos: o Juiz, geralmente mais de um; o Procurador, ou os Procuradores, cargo de alta responsabilidade, já que lhe cabe estar informado da vida particular de cada irmão e proporcionar-lhe ajuda caso necessário, verificando também se são cumpridores de suas obrigações. Dos grêmios também fazem parte Escrivão e Tesoureiro, que devem saber ler e escrever, além de outras figuras secundárias" (Scarano 1976: 29 e 30).
} 
pôde, aos recursos e apoios dos quais poderia dispor no momento. Quem compartilhava dessa mesma opinião era o Administrador da Capela da Lapa, Luís Antonio de Miranda, que, em representação ao Imperador, classificava como um contra-senso uma irmandade que mal conseguia sobreviver, que não possuía recursos para realizar a festa da santa de sua devoção e notoriamente apresentava pouca representatividade na cidade, manifestasse o desejo de reparar e manter uma capela arruinada como a da Lapa. Provavelmente o Administrador temia perder sua posição e, dessa forma, era contrário à cessão da capela, além de se demonstrar um aliado dos Carmelitas (Mendes 1980: 101-102).

Em 23 de dezembro de 1826, os irmãos da Boa Morte procuraram rebater as informações passadas pelo Prior e pelo Administrador de Capelas. Entre outros aspectos abordados, esclareceram que não aumentavam o número de seus integrantes e nem realizavam um fundo pecuniário que custeasse suas despesas graças aos dissabores pelos quais passavam na convivência com o Carmelo. Isso porque muitos fiéis que concorriam com esmolas ou que pretendiam entrar para a irmandade retrocederam em sua devoção, pois não queriam ser maltratados e constrangidos. Também esclareciam que não tinham o intuito de desprestigiar os Carmelitas, embora denunciassem procedimentos e alianças escusas. O objetivo maior era defenderem-se das acusações lançadas pelo Prior, denunciando que a cumplicidade entre o Carmo e o Administrador de Capelas prejudicava um direito tradicional das Irmandades Leigas de buscarem um "lar" para sua divindade de devoção. Acrescentavam ainda que não pretendiam ficar indefinidamente compartilhando a capela da Lapa. Usariam o edifício apenas até que reunissem pecúlio suficiente para a construção de um templo próprio. Em um universo regalista, onde o catolicismo tradicional e secular dependia do fiel para se manter, o argumento central do discurso dos irmãos da Boa Morte era o risco da perda de membros dos quadros da organização. Assim, finalizavam seu apelo observando que, para efetivar esse projeto futuro ao qual toda irmandade tinha direito precisavam se afastar da convivência funesta com o Carmo que por destratar a irmandade da Boa Morte, afugentava prováveis irmãos 
condenando progressivamente o culto da Senhora à uma futura extinção (Mendes 1980: 108-109).

Provavelmente essa argumentação dos irmãos da Boa Morte possibilitou que a questão se prolongasse por mais um tempo antes de uma solução final. Seguindo os procedimentos burocráticos característicos, ocorreu mais uma grande movimentação de requisições, argumentações e desmentidos. Finalmente em 1827, o Bacharel João Joaquim da Silva, Juiz de Provedoria de Capelas e resíduos, despachava seu parecer, favorecendo os carmelitas, fato que demonstra o poder ainda preservado pela ordem entre as autoridades da Vila:

"Tendo a dar a Vossa Majestade Imperial uma exata informação sobre o requerimento do Juiz e Irmãos da Irmandade da Senhora da Boa Morte, ereta da igreja dos religiosos carmelitas desta vila de Angra dos Reis da Ilha Grande, levo à Augusta Presença de Vossa majestade Imperial, o que bem e exatamente pode obter das partes interessadas e mesmo de muito as pessoas boas da vila.

É sem fundamento, Augusto Senhor, que os Irmãos de Nossa Senhora da Boa Morte requerem a Vossa Majestade Imperial, a trasladação da mesma Senhora para a capela da Senhora da Lapa, por quanto, há setenta anos (como se vê do que respondeu o Prior dos carmelitas), que os Irmãos da Senhora da Boa Morte prestam o religioso culto a mesma Senhora, em o Convento dos carmelitas e até aqui não têm minorado o dito culto à Senhora, só algumas vezes deixaram os Irmãos de festejar a mesma Senhora por falta de meios, nunca cessando os religiosos carmelitas de prestarem os necessários ornamentos para decência e culto da Senhora. Seria ingratidão dos mesmos Irmãos trasladarem para outra capela a Senhora da Boa Morte, sendo por tanto tempo naquele Convento adorada e festejada. Ainda mesmo, Augusto Senhor, que pudessem trasladar a senhora para outra capela, seria de tristeza pública não poder-se continuar com o culto decente que até agora se tem prestado; primeiramente, porque não há rendimento; em segundo lugar, por cessar o auxílio que até hoje tem os religiosos carmelitas prestado; em terceiro lugar, pela razão a mais forte, qual é o não haver na capela da Senhora da Lapa mais que um altar, onde se festeja a mesma Senhora da Lapa; e seria também de grande contestação para o futuro existirem duas Venerandas Senhoras em uma capela arruinada, com um só altar, sem terem os Irmãos da Senhora da Boa Morte rendimento para fazerem um novo altar e, existirem, finalmente, os rendimentos da capela da Senhora da Lapa sequestrados, com os quais se pretendia reedificar a mesma capela. 
São estas, Augusto Senhor, as razões, pelas quais me parece impossível a trasladação da senhora da Boa Morte para a capela da Senhora da Lapa. (...)" (Mendes 1980: 110 e 112).

A Irmandade da Boa Morte também possuía prestígio e tradição. Contudo, é importante notar que estes irmãos viviam sob um Estado de política regalista em relação à Igreja e que desejava custos menores para os gastos dos cofres públicos. Assim, faltava à Boa Morte os meios de sobrevivência e portanto, nesse momento, perdeu a disputa com o Carmo.

Por outro lado, aos carmelitas, foi fundamental o aprendizado adquirido ao longo do processo de controle e restrição do Estado Português e posteriormente do Imperial. Permitiu que tais frades forjassem dentro da comunidade de Angra dos Reis cumplicidades como a do zelador Luís Antonio de Miranda e dessem o devido peso à opinião pública local, de forma que todos os documentos enviados ao Estado Imperial possuíssem um discurso do que era esperado de uma ordem religiosa naquele período do oitocentos. Tal exercício, de uma política informal era a exata medida entre a sobrevivência desses frades e a sua total extinção, fosse pelos esforços do poder público, fosse pelas disputas internas ao mundo eclesiástico onde tradicionalmente a Província Carmelita Fluminense ocupava espaço privilegiado frente às comunidades locais.

Entretanto, sempre segundo Alípio Mendes, não se sabe ao certo como, mesmo com o parecer contrário transcrito anteriormente, ainda no século XIX a imagem da Senhora da Boa Morte foi trasladada para a Capela da Senhora da Lapa e até hoje encontra-se na banqueta inferior do trono do altar-mor da Capela da Lapa.

Esse desfecho indica algumas possibilidades. Entre elas, que o poder carmelita declinou nos anos que se seguiram, ou que o poder da Irmandade da Boa Morte cresceu, ou ainda que esta irmandade aprendeu também a "fazer micropolítica" como a ordem do Carmelo aprendera em tempos anteriores. Entretanto, independente das possibilidades apontadas é lícito afirmar que em algum momento desse período, a política informal carmelitana não mais alcançou êxito e que os frades progressiva- 
mente foram sendo abalroados por novas posturas sobre qual deveria ser seu papel na sociedade Imperial. Todas, prováveis decorrências do processo de aprofundamento das restrições do Estado contra esses regulares.

\section{Referências Bibliográficas}

ALMEIDA, Fortunato de. História da Igreja em Portugal. Volume I, Coimbra, 1926.

ALTOÉ, Valeriano. O Altar e o Trono - Um Mapeamento das Idéias Políticas e dos Conflitos Igreja/Estado no Brasil (1840/1889). Tese de Doutorado, UFF, Rio de Janeiro, 1993, (mimeo).

BARBOSA, R. Os Antigos Conventos e seus Bens. São Paulo, Typ. do Brasil, 1902.

BENEDETTI FILHO, Francisco. A Reforma da Província Carmelitana Fluminense (1785/ 1800). Dissertação de Mestrado, USP, São Paulo, 1990, (mimeo).

BOAGA, Emannuele (O.C.). Como Pedras Vivas ....., para ler a História e a Vida do Carmelo. Roma, Impresso nas Oficinas da Litografia Príncipe, 1989.

BRUNO, Ernani da Silva. História e Tradições da Cidade de São Paulo. Três Volumes, Rio de Janeiro, José Olympio, 1953.

CAMARGO, Monsenhor Paulo Florêncio da Silveira. A Igreja na História de São Paulo (1821/1851). $6^{\circ}$ Volume, São Paulo, Instituto Paulista de História e Arte Religiosa, 1953.

CARVALHO, Mariza Soares de. Devotos da Cor. Identidade étnica, religiosidade e escravidão no Rio de Janeiro, século XVIII. Rio de Janeiro, Civilização Brasileira, 2000.

DONINI, Ambrogio. História do Cristianismo. Das Origens à Justiniano. Lisboa, Edições $70,1988$.

FIGUEIREDO, Aldrin Moura de. Inimigos de classe e irmãos de fé: escravos e senhores nas irmandades religiosas na Amazônia do século XIX. 2001 (mimeo).

FONTOURA, Ezechias Galvão. A Vida de D. Antonio J. de Mello, bispo de São Paulo. São Paulo, Escola Typografica Salesiana, 1898.

HOORNAERT, Eduardo. História da Igreja no Brasil. Ensaio de interpretação a partir do povo. A Igreja no Brasil no século XIX.. Petrópolis, Editora Vozes, 1992.

LOPES, Francisco Antônio. História da Construção da Igreja do Carmo de Ouro Preto. Publicações do Serviço do Patrimônio Histórico e Artístico Nacional, número 8, Rio de Janeiro, 1942. 
MENDES, Alípio. O Convento de Nossa Senhora do Carmo da Ilha Grande. Apontamentos para a História dos Frades Carmelitas em Angra dos Reis. Gráfica Olímpica Editora, Rio de Janeiro, 1980.

MOLINA, Sandra R. (Des)obediência, barganha e confronto: a luta da Província Carmelita Fluminense pela sobrevivência (1780/1836). Dissertação de Mestrado. Unicamp, Campinas, 1998, (mimeo).

MOURA, Paulo Cursino de. São Paulo de Outrora, Evocações da Metrópole. 2 Edição, São Paulo, Livraria Martins Editora, 1943.

Pastoral do Episcopado Brasileiro ao Clero e aos Fiéis. Edição da Tipografia de Jorge Sckler \& Comp., São Paulo, 1890.

PINHEIRO, Joaquim Caetano Fernandes. "Os Padres do Patrocínio ou Porto Real de Itu". Revista do Instituto Histórico e Geográfico Brasileiro. 33(1870):139.

PRATT, Frei André (O.C.). Notas Históricas sobre as Missões Carmelitas no Extremo Norte do Brasil. Séculos XVII e XVIII. Recife, 1941.

RICCI, Magda Maria de Oliveira Ricci. Assombrações de um Padre-Regente: Diogo Antonio Feijó (1784/1843). Tese de Doutorado, Unicamp, Campinas, 1998, (mimeo).

REIS, João José. A Morte é uma Festa. Ritos Fúnebres e Revolta Popular no Brasil do século XIX. Terceira Edição, São Paulo, Companhia das Letras, 1999.

ROMANO, Roberto. Brasil: Igreja contra Estado.Crítica ao Populismo Católico. $1{ }^{\text {a }}$ Edição, Kairós Livraria e Editora, São Paulo, 1979.

SCARANO, Julita. Devoção e Escravidão. Volume 357, São Paulo, Cia. Editora Nacional, 1976. 